\title{
The Implementation of Literary Sociology Learning Model with Contextual and Spiritual Quotient Approach to Teach Literary Sociology
}

\section{Masnuatul Hawa}

A Student of Post-Graduate Program in Indonesian Language Education Study Program of Sebelas Maret University, Indonesia, masnuatulhawaaufa@gmail.com

\author{
Andayani \\ Sebelas Maret University, Central Java, Indonesia

\section{Suyitno} \\ Sebelas Maret University, Central Java, Indonesia

\section{Nugraheni Eko Wardani} \\ Sebelas Maret University, Central Java, Indonesia
}

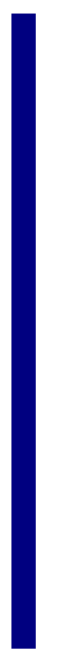

The study of literary sociology is still considered boring for most students. The study of literary sociology is only emphasized on the aspect of theory memorizing. Therefore, implementing learning model with CSQ approach is considered very important to make students active, creative, happy, and have spiritual character. The aims of this study were to know the students' perception towards the implementation of literary sociology learning model with CSQ approach in literary sociology course and to know the effectiveness of literary sociology learning model with CSQ approach to teaching literary sociology compared to the conventional learning model. This research used a mixed-method approach. To answer the first aim of the study, a case study design was used and to answer the second aim of the study the experimental design was used. There were some instruments used in this study such as observation, interview, questionnaire, and test. The qualitative data yielded from observation, interview, and the questionnaire was analysed descriptively; meanwhile, the quantitative data yielded from the test was analysed by using t-test formula. The results show that the students have the positive attitude towards the implementation of literary sociology learning model with CSQ approach.

Keywords: learning model, literary sociology, CTL, CSQ, spiritual quotient, students' perception

Citation: Hawa, M., Andayani, Suyitno, \& Wardani, N. E. (2019). The Implementation of Literary Sociology Learning Model with Contextual and Spiritual Quotient Approach to Teach Literary Sociology. International Journal of Instruction, 12(1), 283-298. https://doi.org/10.29333/iji.2019.12119a 


\section{INTRODUCTION}

Spirituality in learning is important for developing students' character. Dealing with this, many researchers have advocated for school counsellors to assist young people in discovering their spirituality (Allen \& Coy, 2004; Finn Maples, 2001; Ingersoll \& Bauer, 2004; Lambie, Davis, \& Miller, 2008; Rayburn, 2004; Sink, 2004). To promote students' spiritual character in education, the teachers should employ a certain learning model which could influence the students' spirituality in learning. One of the ways that can be implemented by the teachers is by integrating spiritual quotient in their teaching and learning.

Related to spirituality, it is found that the condition of learning the literary sociology theory in Higher Education has not carried out as expected. Teachers tend to use theoretical and rote learning techniques so that learning activities are rigid, monotonous, and boring. Learning materials of literary sociology have not been able to adhere to students as rational, cognitive, emotional, and affective.

The results of the interview with the teachers at Islamic University of Darul Ulum Lamongan (UNISDA), Institute of Teacher Training and Education of PGRI Bojonegoro (IKIP PGRI Bojonegoro), and PGRI Ronggolawe University (UNIROW) Tuban, reveal that there are several factors that cause the learning of literary sociology has not fulfilled the expectation yet. The low students' interest in studying literary is one of the causes of the students' difficulty in understanding the learning of literary sociology. In addition, the improper selection of the learning approach to teaching literary sociology is also an obstacle to achieve literary learning optimally.

Besides spirituality in learning, learning of literary sociology should be oriented to the students' life experience. A meaningful learning of literary sociology is a learning that uses the approach to show evidence, not just theory (Hariwijaya, 2009). One of the learning approaches that prioritize the attention to the daily life experiences construction is the Contextual Teaching and Learning approach. CTL approach is a learning approach that prioritizes concept-building through events that occur around the students (Dewey, 2007). Then, to accommodate the students' spirituality in learning, CTL can be integrated with spiritual quotient (later is called 'CSQ approach') in its implementation. Various events and experiences that students have at the same time can be utilized for spiritual development through the literary sociology learning model.

\section{Research Questions}

From the background of the research above, the researchers formulate the statement of problems as follows.

1. What is the students' perception towards the implementation of literary sociology learning model with CSQ approach in teaching literary sociology course?

2. Is literary sociology learning model with CSQ approach more effective than the conventional learning model in teaching literary sociology? 


\section{Research Objectives}

Based on the formulated research questions above, the objectives of the research are:

1. To reveal the students' perception towards the implementation of literary sociology learning model with CSQ approach in teaching literary sociology course.

2. To investigate whether literary sociology learning model with CSQ approach is more effective than the conventional learning model in teaching literary sociology.

\section{LITERATURE REVIEW}

\section{Learning Model}

According to Slavin (2010), the learning model is a reference to a learning approach that includes goals, syntax, environment, and management system. A good learning model is used as a reference for planning in learning in the classroom or tutorial to determine the learning tools in accordance with teaching materials to be taught.

Suyitno (2002) states that the learning model is a pattern or exclusive learning steps that are applied with the aim that the expected competence of learning outcomes can be achieved effectively and efficiently. Suryaman (2012) states that a learning model is a conceptual framework that describes systematic procedures in organizing learning experiences to achieve specific learning goals and serves as a guide for learning designers and instructors in planning and implementing learning activities. Mars (1996) states that teachers must have the competence to teach, motivate learners, produce an instructional model, manage a class, communicate, plan and evaluate learning. All of these competencies support teacher's success in teaching. Every teacher must have the adaptive competence to every development of science and progress in the education field, both concerning the improvement of learning quality and all matters which is related to the improvement of students' learning achievement.

According to Arrend (2001) there are four things that are closely related to the learning model, namely: 1) the logical rational theory developed by the model developer; 2) the point of view/basis of thinking about what and how students learn; 3) the teacher's behaviours which ensure that the learning model is going well; and 4) the required-class structure to achieve the learning objectives optimally. In acquiring information and developing an understanding of topics, students learn how to construct, organize, collect and analyse data, construct facts, construct arguments, and work individually or collaboratively in solving problems.

Based on some opinions above, it can be synthesized that the learning model is a conceptual framework that presents systematic learning procedures in organizing learning experiences to achieve learning goals. Learning model serves as a guide to learning.

\section{Literary Sociology}

The rationalization of literary sociology research was firstly introduced by Glickberg (1967). He states that all literature, however fantastic or mystical in content, is animated 
by a profound social concern, and this is true of even the most flagrant nihilistic work. This opinion explains that what kind of literary works (fantastic and mystical) will have great influence on social phenomena. A literary work can be said as a complete work when it shows the events that exist in the community.

The notion of literary sociology according to Wolff (1994) is an unformed, undefined discipline composed of a number of empirical studies and experiments on somewhat more general theories, each of which has only the same in common that all deal with literary relationships with the public. The existence of literary cannot be separated from the phenomenon of events and community life. In contrast, all human social stories can be an inspiration to create a literary work.

Goldmann (1991) also states that the sociology of literature is a research focused on human problems, because literature often reveals the human struggle in determining its future, based on imagination, feeling, and intuition. From this opinion, it shows that the long struggle human life will always colour the literary work. Dealing with this 'struggle', Goldmann (1981) states that it has three basic characteristics, namely: (1) the tendency of humans to adapt themselves to the environment, (2) the tendency to coherence in the global process of structuring, and (3) by itself it has dynamic properties and a tendency to change structure even though humans are part of that structure.

From some of the above opinions, it can be concluded that the literary sociology is a study of literary-focused on human social problems. Social issues that are targeted in sociology research include the author's sociology which discusses the author with his social life, the literary sociology works, and the sociology of readers who discuss readers with social life.

\section{CSQ Approach}

\section{Contextual Teaching and Learning (CTL)}

Andayani (2015), states that contextual approach refers to a holistic educational process and aims at motivating students to understand the learning materials as well as to relate them to their daily lives contexts (contexts of personal, social, and cultural). As a result, students will have knowledge or skill which then can be implemented in flexible ways from one problem to another and from one context to another.

Contextual Teaching and Learning (CTL) is a concept relating the subject content with the real world to motivate students to make a correlation between knowledge and its implementation according to their lives as a family member, citizen, and labour force (Blanchard, 2001). The contextual approach recognizes that the students' natural and environmental conditions help to clarify students' knowledge of learning concepts and theories. Through relationships within and outside the classroom, a contextual approach makes the experience more relevant and meaningful to students.

In contextual learning, the task of teachers is to help students achieve their goals. Therefore, teachers' duties are more related to the design of learning strategies, not just information givers. Professional teachers are in charge of guiding students to learn by 
themselves, discovering and constructing their own knowledge in learning is useful for their future life.

In short, Contextual Teaching and Learning (CTL) refers to a learning concept which connotes their knowledge and activities according to seven main components of learning: 1) constructivism, 2) questioning, 3) inquiry, 4) learning community, 5) modelling, 6) reflection, 7) authentic assessment.

\section{Spiritual Quotient}

Intelligence is one of the great graces of God to humans who become one of the advantages of human beings compared with other creatures of God. According to Covey (2004, p.53), spiritual intelligence is the central and most fundamental of all intelligence because it becomes the source of guidance of the other intelligence. Spiritual intelligence represents our drive for meaning and connection with infinite. This opinion confirms that spiritual intelligence is a bridge that can connect and balance the development of other dimensions of intelligence that are naturally given by God. Woolfolk (1975) argued that intelligence includes three meanings, namely: (1) the ability to learn; (2) the overall knowledge gained; and (3) the ability to adapt to new situations or the environment in general.

According to Brightman (1956), religious appreciation does not only come to the recognition of God's existence as the source of eternal values that govern the order of life of the universe. Therefore, humans will strive to obey Him with full awareness and accompanied by surrender in the form of certain rituals, either individually or collectively, symbolically or in tangible form.

Another opinion was expressed by Zohar and Marshall (2001) stating that in the human brain there is a God Spot which becomes the spiritual centre that lies between the nerve and brain tissue. Zohar and Marshall (2001) define spiritual intelligence (Spiritual Quotient) as the intelligence to confront the question of meaning or value, the intelligence to put our behaviour and life in the context of broader meaning, the intelligence to judge that one's actions or way of life are more meaningful than the one other. SQ is the necessary foundation for the effective functioning of Intelligent Quotient (IQ) and Emotional Quotient (EQ). SQ is considered to be the highest intelligence that becomes the basis of other intelligence.

From the various opinions above, it can be synthesized that spiritual intelligence is the ability of self-transcendence to connect the beliefs and values to be able to understand the meaning, value, moral, love of fellow creatures as a part of the whole, purpose, and nature of life from which we come from, for what we live in the world and where we will return.

\section{METHOD}

\section{Research Design}

This research used a mixed method research approach with quantitative and qualitative research data. Johnson and Christensen (2007) state that a mixed method research 
design is the research method combine between quantitative and qualitative method. The scopes of mixed-method research design are the basis of philosophy, qualitative and quantitative approach, and combining those qualitative and quantitative approaches in the research. Mixed method research design can be used to gain the more comprehensible data, valid, reliable and objective. By mixed method research design, the reliability of the data can be increased.

The research designs used in this study were the case study and experimental research design. The case study design was used to answer the first aim of the study; meanwhile, the experimental design was used to answer the second aim of the study. The experimental design used in this study was the study group design proposed by Fraenkel and Wallen (1990), there are two trials groups, experimental and control groups.

\section{The Population and Sample}

The population in this research was all first-grade university students of Indonesian Language Education Study Program in ex-residency of Bojonegoro. The total student was 180 students. The sampling techniques used in this research were purposive sampling and cluster random sampling. The purposive sampling was used to choose the sample for conducting the interview, observation, and questionnaire distribution. The cluster random sampling was used to choose the sample for the experimental stage. From all the classes were taken 2 classes randomly, one class as the experimental group was treated by using learning model of literary sociology with CSQ approach and one control class was treated by using conventional learning model. The students of UNIROW Tuban were the sample to test the validity of the matter. The students of IKIP PGRI Bojonegoro were the sample to conduct experimental group with the total number of 60 students, and the students of UNISDA Lamongan were the sample for the control group with the total number of 60 students. Before the treatment was given, the samples must be in a balanced condition.

\section{Research Instruments}

\section{Observation}

An observation was conducted to know the condition of literary sociology learning process by implementing literary sociology learning model with CSQ approach. It was also used to know the students' response, perception, and class situation during its implementation in literary sociology class. This observation was conducted in three different universities which are previously mentioned. There was one class of literary sociology which was observed from each university. So, there were 3 classes altogether. The chosen classes were taken based on purposive sampling with the reason that all members of the classes chosen were ready to be observed and had a strong will to get involved in the study.

\section{Interview}

An interview was used to gain the information related to the students' perception towards the implementation of literary sociology learning model with CSQ approach in literary sociology class. In order to get more comprehensive data, the questions used in 
the interview were open-ended questions. There were 15 students who were chosen purposively for this interview. There were 5 students taken from each observed class for the interview.

\section{Questionnaire}

A questionnaire was also distributed to the students from the observed classes. The questionnaire was in the form of closed-ended questions. The response mode of the questionnaire used was scaled response mode that was based on the Likert scale. So, there were four options for students to choose namely SA (Strongly Agree), A (Agree), D (Disagree), SD (Strongly Disagree). This questionnaire was also used as a triangulation technique from the data yielded from observation and interview.

Test

A test is pivotal to be used because from the test the researchers get the data and know the effectiveness of literary sociology learning model with CSQ approach. The researchers used multiple choices test to measure the students' understanding of literary sociology. The test instrument was first tested its validity and reliability before it was tested to the students.

\section{Validity}

In this research, the researchers used content validity. The procedures of this content validity are creating the blueprint of the test; creating the test and then analysing the test. Budiyono (2003, p.59) stated that in the process of instruments validation should be carried out expert judgment (the assessment which is done by the expert). In this research, there are two experts who assess the validation of the test. The criteria assessment of the test are (1) the test is appropriate with the blueprint, (2) the material of the test can be understood by the students, (3) the diction can be understood by the students, (4) the question is not ambiguity, (5) the test is not so easy and so difficult.

\section{Reliability}

The results of the data from the try out were analysed their reliability by using Kuder Richardson KR 20. it is a coefficient of reliability to show the variation from items and to answer the right and wrong questions with 0 and 1 score. (Guilford and Benjamin: 1978). As the result, the Kuder Richardson KR 20 was 0.894 . If the result $>0.70$, it means that the data is reliable. Therefore, it could be assumed that the data was reliable.

\section{Data Analysis}

Since there were two kinds of data in this study, qualitative and quantitative data, thus there were two different techniques of data analysis. The qualitative data were dug up in order to answer the first aim of the study and the quantitative data was dug up in order to answer the second aim of the study. The qualitative data yielded from observation, interview were analysed descriptively, and then were compared with the results of the questionnaire in order to guarantee the validity of the data resulted from observation and interview. The latter kind of data, the quantitative data, resulted from the multiple 
choices test was analysed statistically by using the $t$-test formula. Before it was analysed by using the t-test, it was preceded by the normality test and homogeneity test. The normality test was done using Lielifors test; meanwhile, the homogeneity test was done using $F$-test.

\section{FINDINGS AND DISCUSSION}

The students' Perception towards the implementation of literary sociology learning model with CSQ approach in the literary sociology course

To know the students' perception towards the implementation of literary sociology learning model with CSQ approach in the literary sociology course, some techniques were implemented, i.e. observation, interview, and questionnaire.

The observation was done in 3 classes from 3 different universities. The first observation was from the class from IKIP PGRI Bojonegoro which taught literary sociology. From the first observation and field notes, it was found that the students responded positively on the use of literary sociology learning model with CSQ approach in the literary sociology course. The students were enthusiastic to follow the lesson given. They have a high interest and motivation. Moreover, the students were asked to learn in a group. In group learning, all group members play an active role. They also asked the lecturers if there were things that were poorly understood and unclear. By involving spiritual quotient, the students were deeply touched their heart by the teacher. The teacher had successfully influenced the students in learning. Thus, the students have fully participated in the lesson. Even the students were able to express their spiritual character during the teaching and learning process. The students followed the teacher's instruction and obey what the teacher said. This is one of the spiritual characters; it is obedience to the teacher.

The second observation was done in literary sociology class from UNIROW Tuban, East Java. From the observation and field notes, it was revealed that the CSQ approach was implemented well. The students learn the materials of literary sociology contextually. Besides, to accommodate the spirituality in learning, the teacher integrated CTL with the principles of SQ into the teaching and learning process. The teacher asked the students to do the task in the group and then they had to present their work together in front of the class. Through those activities, some spiritual characters were built, such as respecting others, responsibility, friendship skills, honesty, caring, and fairness. The students seemed very enjoy and happy to learn the literary sociology.

The result of the third observation which was conducted in UNISDA Lamongan, East Java, also reveals similar things. The students reacted positively towards the implementation of CSQ approach in learning literary sociology. The students did the tasks given fairly and honestly. They also work in a group and help each other among the group members. When the students presented the results of their work in front of the class, the teacher gave critical suggestion fairly. Those activities, indirectly, could stimulate students' spirituality and build their good character. 
The next instrument that was used to reveal the students' perception towards the implementation of literary sociology learning model with CSQ approach was the interview. This interview was conducted with 15 students from 3 universities. Here are some excerpts of the interview:

Researcher : What is your opinion about the teaching and learning process of literary sociology course?

Student $1 \quad$ : I think it is very good. We learn the material from something concrete. And of course, based on context.

Researcher : Do you think that the teaching and learning process also involved character building?

Student $1 \quad$ : Yes. I think the teacher taught us very well. The character building was taught implicitly in some activities such as group work. We know that in group work, we can respect each other; we have to be fair in accepting or refusing other's opinion, and so on.

Researcher : So, you felt happy with the teaching and learning process?

Student $1 \quad$ : Sure, of course.

Meanwhile, another student from UNIROW Tuban also has similar opinion dealing with the implementation of literary sociology learning model with CSQ approach. The following is the excerpt of the interview.

Researcher : What do you think about the teaching and learning process of literary sociology course?

Student $8 \quad$ : oh ya... I was so motivated with the learning activities in learning literary sociology. The thing that makes me so motivated was we learned it contextually. Besides, we were also asked to do some activities that could encourage us in learning literary sociology through group discussion. I like discussion very much.

Researcher : hmm... ya.. good. What can you learn group discussion? I mean such as character values you take from the group discussion.

Student $8 \quad$ : Hm.. ya.. by group discussion we can share our opinion and respect other's opinion. We can also learn how to be responsible for our task given to us.

Researcher : Anything else?

Student $8 \quad$ : mmmm.... it can also make us better in friendship. Hehe (laughing)

Another student from UNISDA Lamongan also has the positive view towards the implementation of literary sociology learning model with CSQ approach. This is the excerpt of the interview.

Researcher : Would you please to give your opinion dealing with the teaching and learning process in literary sociology class?

Student $13 \quad$ : Mmmm... sure. To me, the teaching and learning process was very challenging. Before, literary sociology is a boring subject because the learning activities were monotonous. But, now, it becomes more interesting.

Researcher : Really? Why interesting? Could you share with me, please!

Student $13 \quad$ : Well, now the teaching and learning activities in literary sociology 
were challenging. That's why it is interesting. We learn the topic based on the contextual problem. Then, we also worked in the group to discuss the problem.

Researcher : : Ok.. Do you learn something from the group work?

Student $13 \quad$ : Sorry, could you explain what do you mean?

Researcher : :Mm.. ya. I mean do you learn about the character values from the group work activities?

Student $13 \quad$ : oh yaa.. Character values. Sure, from the group work, I can learn how to be a good partner in the discussion, I can learn how to respect other's opinion, I can learn how to be responsible, and many things.

From the excerpts of the interview above, it can be inferred that the students have the positive attitude towards the implementation of literary sociology learning model with CSQ approach. They also asserted that they learn the course contextually and they also learn spiritual character through learning activities they did such as respecting others, responsibility, honesty, friendship skills, caring, fairness, and so on.

The last instrument that was used to reveal the students' perception towards the implementation of literary sociology learning model with CSQ approach was the questionnaire. The questionnaire was distributed to 180 students from 3 universities. There are 11 statements in the questionnaire. They are as follows.

Table 1

The Statements of the Questionnaire

\begin{tabular}{|c|c|c|c|c|c|}
\hline \multirow{2}{*}{$\begin{array}{c}\text { No } \\
\text {. }\end{array}$} & \multirow[b]{2}{*}{ Statement } & \multicolumn{4}{|c|}{ Answers } \\
\hline & & $\begin{array}{l}\text { Strongly } \\
\text { Agree }\end{array}$ & Agree & Disagree & $\begin{array}{l}\text { Strongly } \\
\text { Disagree }\end{array}$ \\
\hline 1 & $\begin{array}{l}\text { The teaching and learning process in } \\
\text { literary sociology is based on the } \\
\text { contextual problem }\end{array}$ & & & & \\
\hline 2 & $\begin{array}{l}\text { From the learning activities in the literary } \\
\text { sociology course, I can learn honesty }\end{array}$ & & & & \\
\hline 3 & $\begin{array}{l}\text { From the learning activities in the literary } \\
\text { sociology course, I can learn friendship } \\
\text { skills }\end{array}$ & & & & \\
\hline 4 & $\begin{array}{l}\text { From the learning activities in the literary } \\
\text { sociology course, I can learn fairness }\end{array}$ & & & & \\
\hline 5 & $\begin{array}{l}\text { From the learning activities in the literary } \\
\text { sociology course, I can learn caring }\end{array}$ & & & & \\
\hline 6 & $\begin{array}{l}\text { From the learning activities in the literary } \\
\text { sociology course, I can learn to respect } \\
\text { others }\end{array}$ & & & & \\
\hline 7 & $\begin{array}{l}\text { From the learning activities in the literary } \\
\text { sociology course, I can learn } \\
\text { responsibility }\end{array}$ & & & & \\
\hline 8 & $\begin{array}{l}\text { From the learning activities in the literary } \\
\text { sociology course, I can learn service to }\end{array}$ & & & & \\
\hline
\end{tabular}




\begin{tabular}{|c|c|c|c|c|c|}
\hline \multirow{2}{*}{ No } & \multirow[b]{2}{*}{ Statement } & \multicolumn{4}{|c|}{ Answers } \\
\hline & & $\begin{array}{l}\text { Strongly } \\
\text { Agree }\end{array}$ & Agree & Disagree & $\begin{array}{l}\text { Strongly } \\
\text { Disagree }\end{array}$ \\
\hline & others & & & & \\
\hline 9 & $\begin{array}{l}\text { I am motivated in learning literary } \\
\text { sociology }\end{array}$ & & & & \\
\hline 10 & I am happy to learn literary sociology & & & & \\
\hline 11 & $\begin{array}{l}\text { Literary sociology course is not boring } \\
\text { because we have challenging activities }\end{array}$ & & & & \\
\hline
\end{tabular}

After the questionnaire was distributed to the 180 respondents, the results are presented as in the following figure.

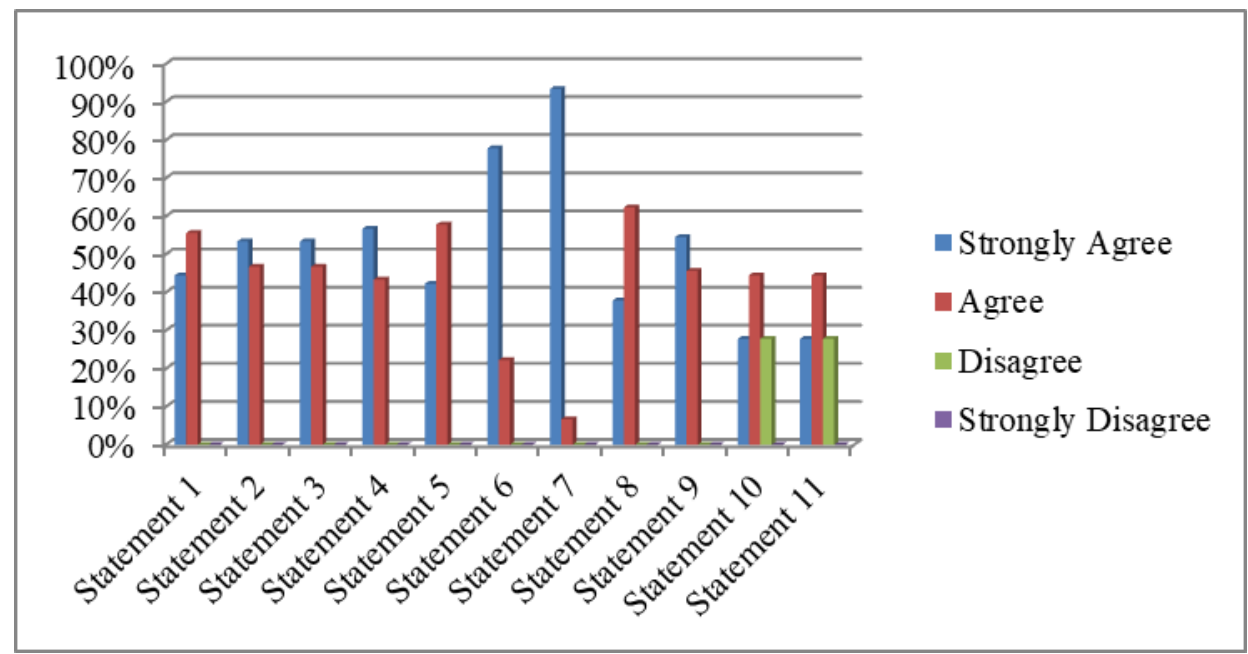

Figure 1

The Results of the Questionnaire Distribution

From the figure 1 above, it can be inferred that the students have positive perceptions towards the implementation of literary sociology learning model with CSQ approach. They were happy and motivated to learn literary sociology. They assert that the learning of literary sociology is longer boring since the learning activities were challenging and motivating. These results are in line with the study of Ghufron \& Ermawati (2018) which mention that innovative teaching and learning technique is needed in order to raise the students' motivation in learning. Besides, the technique should not only attractive and joyful but also promote other aspects such as character building.

Besides, from the learning activities implemented in teaching and learning literary sociology course, the students can learn character values or spirituality such as honesty, responsibility, friendship skills, fairness, caring, respecting others, servicing to others, and so on. These results are in line with Dobmeier's (2011) study which mentions that spirituality or spiritual characters such as caring, integrity, fairness, respect, 
responsibility, honesty, and trustworthiness are pivotal in learning. Teachers should be able to integrate those aspects into their teaching and learning process.

The effectiveness of literary sociology learning model with CSQ approach compared to the conventional learning model in teaching literary sociology

\section{Pre-Test Data (for balancing test)}

To know the effectiveness of literary sociology learning model with CSQ approach, the researchers used a t-test formula for analysis. Since this stage used an experimental design, the students' condition must be the same between the two groups, experimental and control groups, before the treatment was implemented. To know the students' initial condition, the researchers used pre-test. Based on data obtained, the mean score of the pre-test for the experimental class was 60 , and the control class was 63 .

Furthermore, the data obtained were analysed their normality. The results of the normality test of the experimental class show that $\mathrm{L}_{\mathrm{obs}}=0.1121$ and $\mathrm{L}_{\text {table }}=0.1144$. The results of normality test of Control class show that $\mathrm{L}_{\mathrm{obs}}=0,1024$ and $\mathrm{L}_{\text {table }}=0,1116$. Since the value for each sample was $\mathrm{L}_{\mathrm{obs}}<\mathrm{L}_{\text {table }}$, so $\mathrm{H}_{\mathrm{o}}$ was accepted. This means that the data came from normal distribution.

After the data was tested its normality, the next is the homogeneity test of variance between the two groups by using $F$-test with 5\% significance level, the results show that $\mathrm{F}_{\text {obs }}=1.4875<1.5283=\mathrm{F}_{\mathrm{t}}$ so it can be concluded that the sample comes from the homogeneous population. After that, the balance test between the two groups was done by using $t$-test. The results show that of $\mathrm{t}_{\mathrm{obs}}=0,9107$, and $\mathrm{t}_{\text {table }}=1.9794$, thus $\mathrm{t}_{\mathrm{obs}}<\mathrm{t}_{\text {table }}$, so it is concluded that both groups are in balance.

\section{Post-Test Data}

After knowing that the condition of the two classes is balanced, then the different treatment was given to the two classes (groups). The experimental class was treated by using literary sociology learning model with CSQ approach, and the control class was treated by using the conventional learning model. After the learning ends, the students were given post-test to know their achievement of learning on literary sociology materials.

After that, the two groups were tested for final post-test. The mean score of the experimental class (literary sociology learning model with CSQ approach) of the firstsemester students of Indonesian Education Study Program was 84.00, while the mean score of the Control class (conventional learning model) was 61.14. Then, the data was tested its normality and homogeneity as a prerequisite testing.

The results of the normality test of the experimental group show that $\mathrm{L}_{\mathrm{obs}}=0.1131$ and $\mathrm{L}_{\text {table }}=0.1144$. The results of normality test of Control group show that $\mathrm{L}_{\mathrm{obs}}=0,1093$ and $L_{\text {table }}=0,1116$. Since the value for each sample was $L_{\text {obs }}<L_{\text {table }}$, so $H_{0}$ was accepted. This means that the data came from normal distribution. 
The homogeneity test of variance between the two groups also used the F test with a $5 \%$ significance level. The results show that Fobs $=1,2041<1,5283=\mathrm{F}_{\text {table, }}$, so it can be concluded that the sample came from the homogeneous population. After the data from student achievement on literary sociology material was normal and homogeneous for experiment class and control class, then the hypothesis test was done by using $t$-test.

The result of $t$-test with significance level of 0,05 was 19.8466 while $t_{0,05 ; 40}=1.9794$, from $\mathrm{t}_{\text {table, }}$, it was obtained the critical area $\left.=\{\mathrm{t} \mid \mathrm{t}>1.9794)\right\} \mathrm{t}_{\mathrm{obs}} \notin$ critical area. Therefore, $\mathrm{H}_{\mathrm{o}}$ was rejected, so it can be concluded that the literary sociology learning model with CSQ approach is more effective to teach literary sociology than the conventional learning model.

In the learning model of literary sociology with CSQ approach, the teachers convey the material based on the systematic steps of CSQ learning model, so that the learning objectives can be achieved with optimally, in addition, the concept of learning with CTL approach is in accordance with the concept of learning model of learning literary sociology namely "learning must be packed into a process of constructing rather than receiving knowledge" (Sumardjo \& Saini, 1997, p.123).

The results of this study were in accordance with research conducted by Cochran (2007) which states that the benefits of learning with Contextual Teaching and Learning approach for students can deepen understanding and improve problem-solving. In teaching and learning process, the students are involved in an activity that requires them to construct and understand the concepts or material being studied. Through the formation of the learning community, the students can discuss and communicate each other actively, so it can provide reinforcement of understanding and knowledge of students.

\section{CONCLUSION}

To sum up, this study was intended to know the students' perception towards the implementation of literary sociology learning model with CSQ approach in literary sociology course; and to know the effectiveness of literary sociology learning model with CSQ approach to teaching literary sociology compared to the conventional learning model. From the findings, it can be concluded that the students responded positively toward the implementation of literary sociology learning model with CSQ approach in the literary sociology course. They were happy and motivated to learn literary sociology. They assert that the learning of literary sociology is longer boring since the learning activities were challenging and motivating. Besides, from the learning activities implemented in teaching and learning literary sociology course, the students can learn character values or spirituality such as honesty, responsibility, friendship skills, fairness, caring, respecting others, servicing to others, and so on.

After knowing the results of the t-test, it can be concluded that the learning model of literary sociology with CSQ approach yields better achievement in understanding literary sociology than the conventional learning model. The use of literary sociology learning model with CSQ approach on the first-grade students is very helpful in improving students' ability to understand the theory of literary sociology. This 
improvement is due to the literary sociology learning model with CSQ approach is suitable to be applied to the subject of literary sociology theory. In addition, the literary sociology learning model with CSQ approach is also able to develop spiritual quotient of students, various intelligence that appears include personal awareness, personal skills, social awareness, and social skills.

As the implication of this study, the teachers should be aware of their teaching and learning models, techniques, and activities to teach literary sociology course. The appropriate learning models, techniques, and activities will make the students motivated, encouraged, and happy. Moreover, they should also aware with spirituality aspects of learning in which they can build the students' character. Thus, choosing appropriate learning models, techniques, and activities and integrating spirituality aspects in learning are pivotal for teachers.

\section{Acknowledgment}

This research is partly funded by the Indonesian Ministry of Research, Technology, and Higher Education on doctoral dissertation research scheme. We also would like to thank IKIP PGRI Bojonegoro, PGRI Ronggolawe University Tuban, and Darul Ulum Islamic University Lamongan for providing the research access and ethical clearance for the research participants.

\section{REFERENCES}

Allen, J. M., \& Coy, D. R. (2004). Linking Spirituality and Violence Prevention in School Counseling. Professional School Counselling, 7,351-355.

Andayani. (2015). Problema dan aksioma dalam metodologi pembelajaran bahasa Indonesia [The problems and axioms in the methodology of learning the Indonesian language]. Yogyakarta: Deepublish.

Arrends, R.I. (1998). Learning to teach. Singapore: Mc Graw-Hill Book Company.

Blanchard, A. (2004). What is contextual learning and teaching. Retrieved 5 December 2017 from http//www.Besteducationalservice.com/contextual pdf,

Colin \& Mars. (1996). Handbook for beginning teachers. Sydney: Addison Wesley Longman Australia Pry Limited.

Covey, S. R. (2004). The 7 habits of highly effective people: Powerful lesson in personal change. New York: Free Press.

Dobmeier, R. (2011). School Counsellors Support Student Spirituality through Developmental Assets, Character Education, and ASCA Competency Indicators. Professional School Counselling, 14, 5, 317-327.

Finn Maples, M. (2001). Spirituality: Its place in counselling children. In D. S. Sandhu (Ed.), Elementary school counselling in the new millennium (pp. 223-237).Alexandria, VA: American Counseling Association. 
Fraenkel, J.R. \& Wallen, N.E. (1990). How to design and evaluate research in education. New York: Mc.Graw Hill Pub Co.

Ghufron, M. A., \& Ermawati, S. (2018). The strengths and weaknesses of cooperative learning and problem-based learning in EFL writing class: Teachers and students' perspectives. International Journal of Instruction, 11(4), 657-672. https://doi.org/10.12973/iji.2018.11441a

Glikberg \& Charles I. (1967). Literature and society. Nederland: Martinus Nijhoff The Hague.

Goldmann \& Lucian. (1970). The Sociology of literature: Status and problems of method in Milton C Albrecht (Ed) (1981). The sociology of art and literature. New York: Praeger Publisher.

Hariwijaya. (2009). Meningkatkan kemampuan bersastra [Improving literary skills]. Yogyakarta: depublish.

Ingersoll, R. E., \& Bauer, A. (2004). An integral approach to spiritual wellness in school counseling settings. Professional School Counselling, 7,301-308.

Lambie, G.W., Davis, K. M., \& Miller, G. (2008). Spirituality: Implications for Professional School Counsellors' Ethical Practice. Counselling \& Values, 52,211-223.

Rayburn, C. (2004). Assessing Students for Morality Education: A New Role for School Counsellors. Professional School Counselling, 7,356-362.

Sink, C. A. (2004). Spirituality and comprehensive school counselling programs. Professional School Counseling, 7, 309-315.

Sumardjo; Jakop \& Saini K.M. (1991). Apresiasi kesusastraan [Literary appreciation]. Jakarta: Gramedia Pustaka Utama.

Suryaman, M. (2012). Pedoman Penulisan Buku Ajar [the guide of textbook writing]. Makalah. Jakarta: Pusat Perbukuan.

Suyitno. (1985). Teknik pengajaran apresiasi sastra dan kemampuan bahasa [The technique for teaching literary appreciation and language skills]. Yogyakarta: PTHanindita.

Trianto. (2009). Mendesain model pembelajaran inovativ progresif [Designing the model of progressive and innovative learning]. Edisi ke-4 [the fourth-edition]. Jakarta: KencanaPrenada Media Grup.

Tischler, L; Biberman, J \& McKeage, R. (2002). Linking emotional intelligence, spirituality and workplace performance: Definitions, models and ideas for research. Journal of Managerial Psychology. Vol 17, No. pp. 203-218 
Wenitzky, N. E \& Tannenbaum, M. D. (2001). Exploring teaching: An introduction to education. New York: Mc Graw-Hill Companies.

Zohar; Danah \& Marshal I. (2005). Spiritual Capital. Jakarta: Mizan. 